\title{
A SATISFAÇÃO DA TUTELA DE EXIBIÇÃO DE DOCUMENTOS EM SEDE DE AÇÃO POPULAR
}

\author{
THE PROCESS'S EFFECTIVENESS IN POPULAR ACTIONS
}

\author{
Rafael Vieira de Alencar ${ }^{1}$ \\ Felipe Braga Albuquerque ${ }^{2}$
}

\section{RESUMO}

O objetivo geral deste trabalho o estudo dos limites e possibilidades do conhecido "poder geral de efetivação da tutela jurisdicional". Concomitantemente foram delimitadas as balizas estruturantes dos poderes executórios do juiz, notadamente com o objetivo de estabelecer um estudo voltado para o procedimento da exibição de documentos em ação popular, a aplicação de multa diária em caso de descumprimento e/ou a presunção de veracidade dos fatos narrados na inicial popular. No que se refere à metodologia, foi realizada exclusivamente em plano teórico, no qual foram feitas a revisão bibliográfica de direito processual, administrativo e direito político/constitucional.

Palavras-chave: Efetividade da tutela jurisdicional, Limites à satisfação da tutela, Ação popular, Exibição de documentos

\begin{abstract}
The aim of this work the study of the limits and possibilities of the known "general power of realization of judicial protection ". Concomitantly were delineated the structural goals of executory judge's powers, notably with the aim of establishing a study related to the procedure of displaying documents in popular action, the application of a daily fine for noncompliance and the presumption of veracity of the facts narrated in the popular original. As regards the methodology, it has been carried in theory, in which were done the literature review procedural, administrative and political law right.
\end{abstract}

Keywords: Effectiveness of judicial decisions, Satisfaction limits of decisions, Popular action, Documents display

\footnotetext{
${ }^{1}$ Mestrando em Direito pela Universidade Federal do Ceará - UFC, Ceará, (Brasil). É pesquisador em projetos de extensão da Universidade Federal do Ceará - UFC, Ceará, (Brasil). E-mail: rafaelvieira93@ @otmail.com

${ }^{2}$ Doutorado em Direito Constitucional pela Universidade de Fortaleza - UNIFOR, Ceará, (Brasil). Professor pela Universidade Federal do Ceará - UFC, Ceará, (Brasil). E-mail: felipe_direito@ hotmail.com
} 


\section{INTRODUÇÃO}

Sabe-se que a ação popular, um dos mais eficazes instrumentos jurídicos de participação ativa dos cidadãos em prol do controle e proteção do patrimônio público em face de atos ilegais praticados por agentes públicos, apresenta regulamentação específica na Lei $n^{\circ}$ 4.717 de 29 de junho de 1965. No entanto, consoante dispõe o art. $22^{3}$ do referido diploma normativo, aplicam-se, subsidiariamente, as regras do Código de Processo Civil aos processos regulados pela Lei de ação popular, isto é, naquilo em que não sejam contrariadas as disposições especiais, nem a natureza específica da ação, deve-se aplicar a legislação processual civil comum.

Sendo assim, para garantir a eficácia das decisões proferidas em sede de ação popular, incumbe ao magistrado se valer dos mecanismos satisfativos admitidos pela lei adjetiva civil, o que, conforme será exposto ao longo deste trabalho, na grande parte dos casos, não se consegue alcançar um resultado prático efetivo.

Por essa razão, a questão da efetividade das decisões judiciais, temática amplamente abordada e discutida por diversos operadores e pesquisadores da ciência do direito, tornou-se motivo frequente de insatisfação social nos dias atuais. Isso porque, mesmo após notória morosidade da Justiça em se obter um provimento judicial na fase cognitiva, as decisões, por diversas vezes, não possibilitam a entrega do bem da vida em virtude das falhas existentes na tutela satisfativa.

Deste modo, observa-se que a dedicação ao estudo do tema "efetividade do processo" e as reformas das leis processuais são questões que se repetem independentemente da nacionalidade do ordenamento jurídico que se está analisando e nos mais diversos ramos do direito que se efetivam através da lei instrumental.

Nesse ensejo, o que se pretende analisar nesse trabalho são os meios executivos postos à disposição do magistrado, notadamente aqueles de cunho civil ligados à exibição de documentos, em processos que sigam o rito previsto da Lei $n^{\circ} 4.717 / 65$, e em que medida eles são empregados para assegurar a prestação da tutela satisfativa.

\footnotetext{
${ }^{3}$ Art. 22. Aplicam-se à ação popular as regras do Código de Processo Civil, naquilo em que não contrariem os dispositivos desta lei, nem a natureza específica da ação.
} 
No presente artigo, serão problematizados temas relativos à possibilidade de imposição de multa diária como meio coercitivo à exibição de documentos à luz do entendimento do Superior Tribunal de Justiça, no processo de ação popular, pelo polo passivo, além do que dispõe a Lei $\mathrm{n}^{\circ}$ 4.717/65 sobre a exibição de documentos ${ }^{4}$, bem como a possibilidade de aplicação do instituto da presunção de veracidade aos fatos narrados na inicial popular, quando os demandados se quedarem inertes frente ao provimento jurisdicional ordenando a exibição de documentos. A abordagem adentrará na análise de direito processual, direito administrativo e político/constitucional.

A pesquisa, no que se refere à metodologia, foi realizada exclusivamente em plano teórico, no qual foram feitas a revisão bibliográfica de direito processual, administrativo e direito político/constitucional para ressaltar a abordagem crítica dos materiais escolhidos para compor sua produção. Além disso, foram analisados casos práticos, através de decisões, súmulas e informativos do Superior Tribunal de Justiça.

\section{A CRISE DE SATISFAÇÃo NO PROCESSO E NO PROCESSO DE AÇÃo POPULAR}

Existe, sem dúvidas, um movimento de convergência nas civilizações ocidentais que se filiaram ao modelo do Estado Democrático de Direito, quanto à análise dessa temática, que pode ser expressa na tendência de se apontar a deficiência do sistema de justiça estatal na solução dos litígios que lhe são postos.

Sobre a questão da crise de satisfação, a Constituição Federal brasileira não contemplou, de forma expressa, o direito a uma tutela efetiva ${ }^{5}{ }^{6}$. Contudo, através dos

\footnotetext{
${ }^{4}$ Art. $7^{\circ} \mathrm{A}$ ação obedecerá ao procedimento ordinário, previsto no Código de Processo Civil, observadas as seguintes normas modificativas:

I - Ao despachar a inicial, o juiz ordenará:

[...]

b) a requisição, às entidades indicadas na petição inicial, dos documentos que tiverem sido referidos pelo autor (art. $1^{\circ}, \S 6^{\circ}$ ), bem como a de outros que se lhe afigurem necessários ao esclarecimento dos fatos, ficando prazos de 15 (quinze) a 30 (trinta) dias para o atendimento.

[...]

$\S 2^{\circ}$ Se os documentos e informações não puderem ser oferecidos nos prazos assinalados,

o juiz poderá autorizar prorrogação dos mesmos, por prazo razoável.
} 
princípios contidos no texto da carta constitucional, como a garantia do acesso à justiça ${ }^{7}$, do devido processo legal e da razoável duração do processo, todas contidas nos incisos do artigo $5^{\circ}$ da Constituição, torna-se possível inferir que a efetividade do processo encontra-se, ainda que implicitamente, ali inserta.

Ao discorrer sobre a "problemática essencial da efetividade”, Cândido Rangel Dinamarco, retrata quatro perspectivas fundamentais da efetividade do processo: “a) admissão em juízo; b) modo-de-ser do processo; c) critérios de julgamento (ou a justiça nas decisões); d) a efetivação dos direitos (ou utilidade das decisões)", apontando ainda o autor que a efetividade do processo corresponde à capacidade do sistema de realmente produzir as situações de justiça buscadas pelas partes. Eis a relação entre instrumentalidade e efetividade. (2009, p. 273)

No que se refere à tutela executiva, foram muitas as reformas que sofreu o antigo Código de Processo Civil de 1973, sempre buscando retirar os obstáculos à prestação jurisdicional impostos pela duração excessiva do processo. No entanto, mesmo depois dessas mudanças, ainda persistiram a demora ou ausência de efetividade da prestação jurisdicional.

Imprescindível se faz elencar outros fatores que, segundo Marcelo Guerra, contribuem para a mora da prestação jurisdicional, desde falhas estruturais, a saber, falta de aparelhamento judiciário adequado, excesso de demandas executivas e mesmo a má atuação do juiz na aplicação das regras, o que gera uma ineficácia do resultado final do processo, e ainda os custos envolvidos; (2003, p. 74) desencadeando, pois, a seguinte indagação: até que ponto adianta a obtenção de uma decisão favorável se não há meios viáveis de torna-la efetiva?

\footnotetext{
${ }^{5}$ Conduta diversa foi adotada, por exemplo, pela Constituição espanhola, que previu tal direito em seu art. 24, I: "Todas las personas tienen derecho a obtener la tutela efectivade los jueces y tribunales en el ejercicio de sus derechos e intereses legítimos sin que, em ningún caso, pueda producirse indefensión”.

${ }^{6}$ Todavia, cumpre apontar que há autores, como Cassio Scarpinella Bueno, que entendem que o principio da inafastabilidade do controle jurisdicional é sinônimo de efetividade de jurisdição. (2004, p. 22-76).

${ }^{7}$ Para Juvêncio Vasconcelos Viana, não se pode mais ver o acesso à justiça como acesso formal aos tribunais e juízes, um acesso ao judiciário. Deve-se propiciar o acesso à ordem jurídica justa. (2007. p. 13).
} 
A despeito disso, por óbvio, não se está a defender neste trabalho que as decisões judiciais devam ser satisfeitas a qualquer custo, motivo pelo qual se mostra inafastável a imposição de limites para a efetividade, através da própria legislação, v.g., a vedação da prisão civil por dívidas e a impenhorabilidade de determinados bens, como bem aponta a doutrina quando trata da humanização da execução e os limites políticos da execução:

O disposto no art. 620 do Código de Processo Civil situa-se no contexto de um estágio evoluído da execução civil, cuja história bissecular mostra a caminhada de um regime extremamente severo e intolerante, vigente entre os romanos do período pré-clássico (antes do século II A.C.), no sentido de uma humanização compatível com os fundamentos políticos-filosóficos do moderno Estado de direito democrático. A execução perdeu o primitivo caráter punitivo de infâmia, deixou de incidir sobre a universalidade do patrimônio do obrigado sem necessidade e, de passo em passo, chegou ao que hoje temos expresso no dispositivo em exame. Ela é hoje balizada por algumas limitações, os chamados limites políticos da execução, impostos para a preservação da liberdade, da dignidade humana, direito ao patrimônio e, em geral, dos direitos da personalidade. (DINAMARCO, 2007, p. 295296).

Contudo, não é o objetivo desse trabalho se debruçar sobre todos esses aspectos, apesar de se ter em mente que estes têm participação significativa no atual quadro de morosidade na prestação da tutela satisfativa.

Nesse ensejo, insta mencionar o rompimento do dogma da tipicidade dos meios executivos, (ALVARO DE OLIVEIRA, 2008, online) haja vista a redação dada ao $\S 5^{\circ}$ do art. $461^{8}$ do antigo Código de Processo Civil de 1973, por meio da alteração advinda da Lei $\mathrm{n}^{\mathrm{o}} 10.444$ de 2002, ora repetida no art. $536^{9}$ do Novo Código de Processo Civil, faculta ao juiz a determinação das medidas necessárias à satisfação da prestação. Outrossim, tem-se, igualmente, o art. 139, IV, do Novo Diploma Adjetivo Civil, corroborando o aludido entendimento, ao passo que confere ao magistrado a prerrogativa de determinar "todas as medidas indutivas, coercitivas, mandamentais ou sub-rogatórias necessárias para assegurar o cumprimento de ordem judicial".

\footnotetext{
${ }^{8}$ Art. 461, § $5^{\circ}$ CPC de 1973. Para a efetivação da tutela específica ou a obtenção do resultado prático equivalente, poderá o juiz, de ofício ou a requerimento, determinar as medidas necessárias, tais como a imposição de multa por tempo de atraso, busca e apreensão, remoção de pessoas e coisas, desfazimento de obras e impedimento de atividade nociva, se necessário com requisição de força policial.

${ }^{9}$ Da mesma forma, observa-se que o legislador previu a faculdade do juiz de determinar as medidas que entender de direito em prol da efetivação da tutela específica. In verbis: Art. 536 CPC 2015: No cumprimento de sentença que reconheça a exigibilidade de obrigação de fazer ou de não fazer, o juiz poderá, de ofício ou a requerimento, para a efetivação da tutela específica ou a obtenção de tutela pelo resultado prático equivalente, determinar as medidas necessárias à satisfação do exequente.
} 
Assim constata-se que anteriormente predominava o rigor excessivo da tipicidade dos mecanismos de execução, o que acabava por tolher os poderes criativos do juiz, sendolhe vedada a adaptação das medidas para assegurar o cumprimento de suas ordens judiciais, sem que pudesse eleger aquela que se mostre mais eficaz.

Logo, a partir da referida alteração legislativa, foi conferida ao magistrado maior liberdade de escolha dos meios mais eficazes para o cumprimento de suas decisões. Conforme se depreende da inteligência dos artigos supramencionados, foram empregadas as seguintes expressões: "medidas necessárias", "entre outras medidas", "tais como"; restando, pois, inequívoco que se trata de rol exemplificativo (numerus apertus), não havendo mais que se falar em tipicidade dos meios executivos.

Em contrapartida, o que se pretende demonstrar é que, tão somente com o emprego de tais palavras, não se deve entender pela inexistência de limitações aos poderes conferidos aos juízes em relação à tutela satisfativa, eis que mais grave seria tutelar, em abstrato, qualquer espécie de atuação do judiciário destinada a garantir a efetividade das decisões, haja vista a possibilidade de violação de direitos e garantias fundamentais.

Vale mencionar ainda, ao analisar a redação do novo Código de Processo Civil, especificamente sobre o caput do art. $139^{10}$, Roberto Sampaio Contreiras de Almeida avalia que o legislador do novel Código de Processo Civil mantém a preocupação com a efetividade do processo:

No cômputo geral, esse incremento da participação do juiz na direção do processo e, por conseguinte, na sua cooperação para a realização da justiça, pode ser considerado, em última análise, como um alinhamento metodológico do novo Código com as premissas teóricas do instrumentalismo, ou seja, a busca pela otimização do sistema voltada à maior efetividade das decisões judiciais. Nessa linha, devem ser levados em conta os aspectos externos do processo, que são ligados aos seus objetivos e resultados a perseguir, não somente no plano individual, mas, sobretudo, no coletivo e social, na medida em que o processo consiga atingir resultados práticos capazes de contribuir para a almejada pacificação social, considerada escopo magno do processo. (WAMBIER, 2015, p. 448).

${ }^{10}$ Art. 139. O juiz dirigirá o processo conforme as disposições deste Código, incumbindo- lhe: [...]. 
Para o supra referido autor, ainda que a atuação de ofício do juiz não esteja expressa nesse texto, pode-se deduzi-la logicamente do caput do artigo, que trata dos poderes e deveres do juiz na direção do processo, para torná-lo mais justo, célere e efetivo.

Ressalta o fato de que no novo Código de Processo Civil as medidas de apoio à efetivação se encontram limitadas às técnicas processuais para satisfação das obrigações de fazer e não fazer e entrega da coisa, mantendo a tradição do Código de 1973 nas disposições referentes ao cumprimento de sentença que reconheça a exigibilidade de obrigação de fazer, de não fazer ou de entrega de coisa.

Assim, essa liberdade de escolha do juiz permite que ele sempre adapte as medidas para assegurar o cumprimento de suas ordens judiciais, elegendo aquela que se mostre mais eficaz. Isso é justamente o oposto daquilo que se verifica no ordenamento jurídico germânico, onde o rigor excessivo da tipicidade dos meios executivos tolhe os poderes criativos do magistrado.

Resta saber, no entanto, em que medida a nova redação conseguirá aparelhar o juiz para alcançar a tão almejada efetividade no processo de ação popular.

\section{A (A)TIPICIDADE DOS MEIOS SATISFATIVOS NO DIREITO BRASILEIRO}

Inicialmente, mostra-se prudente tecer algumas considerações quanto à questão da tipicidade dos meios executivos, que tem por fito impor delimitações à atuação e à ingerência do Estado na liberdade e na propriedade, proporcionando a garantia ao executado de que este só poderia vir a sofrer limitações decorrentes da efetivação de tutelas jurisdicionais, com um mínimo de previsibilidade, e, especialmente, ciente de antemão acerca de quais seriam as armas passíveis de utilização pelo Poder Estatal durante eventual atuação satisfativa. (BUENO, 2013, p. 173).

Em outras palavras: a tipicidade consiste na ideia de que todos os atos satisfativos estão prévia e pormenorizadamente descritos na lei processual; havendo, porquanto, a necessidade de eleger, tão somente dentre as medidas previstas na legislação, o ato mais adequado $^{11}$. 
Diante disso, não se verifica, pois, a faculdade de escolha dos juízes em relação aos mecanismos de execução a serem adotados quando da ausência de previsão normativa, dado que suas atribuições estão adstritas aos limites impostos pelo diploma adjetivo civil, fazendose necessária a obediência de tais regras.

Contudo, a partir das reformas do antigo Código de Processo Civil iniciadas em 1994, o binômio tipicidade-adequação passou a ser revisto. Isso porque, com a passagem de Estado Liberal para Estado Democrático de Direito, à luz do novo texto constitucional, iniciou-se a propagação da ideia de "modelo constitucional do direito processual civil". Por essa razão, a despeito da percepção tradicional, isto é, daquela que propõe a perspectiva da tipicidade, a análise do caso concreto deu azo a interpretações que concedam ao magistrado a prerrogativa de implementação de técnicas ou de métodos executivos não previstos expressamente em lei, mas compatíveis aos valores ínsitos à atuação do Estado Democrático de Direito, ${ }^{12}$ respeitando-se as garantias processuais fundamentais, corolários do princípio máxime do direito processual, qual seja: o "devido processo legal".

Hodiernamente já não há mais dúvidas acerca da superação da tipicidade dos meios executivos com a adoção da atipicidade dos meios de execução, eis que é facultado ao juiz escolher a melhor técnica executiva para atuar conforme a situação concreta. (MARINONI, 2003, p. 224-225).

Nessa toada, o Novo Código de Processo Civil intensificou os poderes conferidos aos magistrados, visando, sobretudo, o aprimoramento da tutela jurisdicional por meio da criação de um sistema processual capaz de imprimir maior efetividade às decisões judiciais.

\footnotetext{
${ }^{11}$ Cássio Scarpinella Bueno chama de Princípio da Adequação, fazendo alusão entre as diversas modalidades obrigacionais, de forma que se observam regimes processuais distintos conforme se trate de obrigação de fazer, não fazer, dar coisa e "pagar". Assim, caberá ao exequente formular a pretensão adequada, denotando-se a noção de tipicidade. (2013, p. 181).

${ }^{12}$ Sobre o estudo da tutela executiva e seus desdobramentos no exame do caso concreto, assim se pronuncia Luiz Guilherme Marinoni: "Quando se teoriza o tema das "tutelas" se tem em mira exatamente a imprescindibilidade da identificação das situações de direito material para a compreensão crítica da lei processual e para o delineamento das técnicas processuais capazes de outorgar efetividade à prestação jurisdicional e, assim, colocá-la em uma dimensão realmente capaz de concretizar o direito fundamental à tutela jurisdicional efetiva." (2005, p. 6).
} 
Análogo ao aludido revogado art. $461, \S 5^{\circ}$, a atual lei processual viabilizou ao juiz a adoção das medidas que entender necessárias para obter a satisfação do exequente, de acordo com as disposições contidas no art. 536.

Utilizando-se ainda da expressão "medidas necessárias", e ainda buscando outros exemplos de meios de coerção que não a aplicação de multa diária, e considerando que não é possível adotar-se medidas vedadas sistematicamente pelo ordenamento, como a prisão civil, excetuando-se aquela decorrente do descumprimento da prestação alimentícia, deve-se sempre ponderar que a intenção do legislador foi de conferir poder ao juiz para determinar a medida adequada a cada caso concreto.

Assim, excluindo-se a prisão, e incluindo nesse rol a multa, resta analisar se os meios executivos poderiam recair sobre outros direitos, mas "isto não quer dizer, como é óbvio, que o juiz possa deixar de explicar o motivo que o levou a determinar certa medida, uma vez que a sua atuação [...] deve ser controlada através dos princípios do meio mais idôneo e da menor restrição possível".

Há que se citar também a redação do art. 139 do referido diploma processual, notadamente o inciso IV, pelo qual se torna possível a determinação de "todas as medidas indutivas, coercitivas, mandamentais ou sub-rogatórias necessárias para assegurar o cumprimento de ordem judicial", incluindo ainda as ações cujo objeto se trate de prestação pecuniária. É preciso destacar, nesse contexto, que parte da doutrina considera temerária a ampliação dos poderes dos magistrados proposta no Novo Código de Ritos, ressaltando não só a possibilidade de afronta à segurança jurídica e ao devido processo legal, mas também a preocupação com os direitos das partes e dos advogados, os quais se veriam abrandecidos em detrimento das prerrogativas dos magistrados.

Em posição antagônica, Trícia Cabral apresenta posicionamento favorável à ampliação dos poderes do magistrado com o Novo CPC, aduzindo que não acarretará aumento de riscos no que toca ao autoritarismo ou à arbitrariedade por parte desse membro do Judiciário:

O Projeto do novo CPC [...] procurou não só aprimorar as técnicas processuais, mas mexer na própria fisionomia do processo, para que este pudesse ser mais maleável e adaptável aos diversos tipos de conflitos sociais levados a juízo, permitindo um tratamento individualizado às demandas judiciais quando assim o caso merecesse, [...] trazendo mais fluidez ao processo. (CABRAL, 2012, p 278). 
A despeito dessa inquietação, resta saber em que medida a nova redação conseguirá aparelhar o juiz, ou seja, quais são os meios executivos postos à sua disposição, para assegurar a satisfação da tutela, especialmente em sede de processos de ação popular.

\section{A APLICAÇÃO DE MEDIDAS COERCITIVAS NA SATISFAÇÃO DA TUTELA NOS PROCESSOS DE AÇÃO POPULAR}

Quando se utiliza dos meios coercitivos, ${ }^{13}$ objetiva-se suprir, coercitivamente, a vontade do devedor, fazendo com que ele participe do processo de satisfação da obrigação. Podem os meios coercitivos ser de cunho pessoal (quando o descumprimento acarreta a prisão do devedor, por exemplo) ou de cunho patrimonial (quando se pretende compelir o devedor a cumprir a obrigação através da imposição de multa).

De outra feita, através dos meios sub-rogatórios, o Estado, diante da inércia do devedor, toma as medidas necessárias para a satisfação do crédito. Ele pode retirar o bem das mãos do obrigado (desapossamento), pode fazer o que o obrigado deveria ter feito ou desfazer aquilo que o devedor fez indevidamente (transformação), ou realizar o cumprimento de obrigação de pagamento de soma em dinheiro, retirando do acervo patrimonial do devedor os bens necessários (expropriação). (ZAVASCKI, 2001, p. 75-76).

No que pertence especificamente à Ação Popular, instituto de direito constitucional processual destinado a garantir a participação política do cidadão no seio da administração estatal, cumpre destacar que consiste em espécie crucial de realização da soberania popular, viabilizando o exercício da democracia direta. (REIS, 2014, online).

Sendo assim, visando à defesa do direito coletivo ou difuso, o instrumento supramencionado pode ser utilizado por qualquer pessoa, desde que comprovada a cidadania por meio de título de eleitor ${ }^{14}$, para anular ou pedir declaração de nulidade de ato lesivo ao patrimônio público ou de entidade de que o Estado participe, à moralidade administrativa, ao meio ambiente e ao patrimônio histórico e cultural.

\footnotetext{
13 A execução indireta se concretiza através dos meios de coerção: "É dita indireta porque não conduz diretamente à tutela do direito, limitando-se a incidir sobre a vontade do réu para que a tutela do direito seja prestada”. (MARINONI, 2003, p. 13).
} 
Ademais, vale lembrar que as sentenças proferidas nesse contexto apresentam certa particularidade, qual seja: produzem efeitos erga omnes, exceto quando julgada improcedente por deficiência de provas, restando então a possibilidade de ré-propositura da ação desde que com novas evidências, conforme dispõe o art. 18 da Lei $\mathrm{n}^{\mathrm{o}} 4.717 / 85^{15}$. Desse modo, verificada a procedência da ação popular, deverá o juiz decretar a invalidação do ato impugnado; condenar os responsáveis à indenização cabível, além das perdas e danos quando for o caso; e condenar os réus ao pagamento das custas e sucumbência ${ }^{16}$.

Ocorre que, lamentavelmente, não é isso que se tem observado no cotidiano da prática forense. Um dos motivos pelos quais tal instituto vem apresentando diversas falhas na concretização de seus ideais consiste na problemática da "efetividade do processo". Isso porque, não raro, as decisões são descumpridas pelas pessoas jurídicas de direito público (União, Estados-membro, Municípios e Distrito Federal), pelas entidades autárquicas e pelos demais legitimados tratados no $\operatorname{art.~}^{\circ}$ da referida legislação ${ }^{17}$.

Desse modo, nas hipóteses de ação popular intentada com o propósito de demonstrar, v.g., irregularidades ocorridas em procedimentos licitatórios realizados pela Administração Pública. A título de tutela de urgência requerida em caráter antecedente, será requerida a exibição dos documentos relativos à supra referida licitação, os quais se encontram sob o domínio do Poder Público, a fim de que restem comprovadas as irregularidades aduzidas no bojo da ação popular.

${ }^{14} \mathrm{O}$ art. $1^{0}$ da Lei 4.717/65, a qual regula a Ação Popular, dispõe que "Qualquer cidadãoserá parte legítima para pleitear a anulação ou a declaração de nulidade de atos lesivos aopatrimônio da União...".

${ }^{15}$ Art. 18. A sentença terá eficácia de coisa julgada oponível "erga omnes", exceto no caso de haver sido a ação julgada improcedente por deficiência de prova; neste caso, qualquer cidadão poderá intentar outra ação com idêntico fundamento, valendo-se de nova prova.

${ }^{16}$ Celso Antônio de Mello, tecendo comentários sobre o tema, aduz que: "Talvez a única providência judicial temida pelos administradores seja a ação popular, considerando que sua procedência ensejará, além da decretação de invalidade do ato impugnado, a condenação ao pagamento de perdas e danos aos responsáveis pela sua prática e aos beneficiários dele.” (MELLO, 2008, p. 946).

${ }^{17}$ Art. $1^{\circ}$ Qualquer cidadão será parte legítima para pleitear a anulação ou a declaração de nulidade de atos lesivos ao patrimônio da União, do Distrito Federal, dos Estados, dos Municípios, de entidades autárquicas, de sociedades de economia mista (Constituição, art. 141, § 38), de sociedades mútuas de seguro nas quais a União represente os segurados ausentes, de empresas públicas, de serviços sociais autônomos, de instituições ou fundações para cuja criação ou custeio o tesouro público haja concorrido ou concorra com mais de cinquenta por cento do patrimônio ou da receita ânua, de empresas incorporadas ao patrimônio da União, do Distrito Federal, dos Estados e dos Municípios, e de quaisquer pessoas jurídicas ou entidades subvencionadas pelos cofres públicos. 
Caso a administração pública/gestor público descumpra o mandamento judicial de exibição de documentos, diante dessa situação fática, surge um questionamento: estariam os poderes do magistrado de designar medidas para assegurar a eficácia de suas decisões despidos de quaisquer balizas?

\section{AS POSSIBILIDAdES DE SATISFAÇÃO DA TUTELA QUE ORDENA A EXIBIÇÃO DE DOCUMENTOS}

Releva-se importante rememorar, por oportuno, as considerações feitas em momento anterior, quando da abordagem das inovações advindas da nova lei processual, que acabaram por ampliar os poderes dos juízes. Tendo tal fato como ponto de partida, não se pode olvidar, inicialmente, os limites impostos pela atual Constituição Federal aos poderes do magistrado que ora se refere, ao passo que previu extenso rol de garantias e direitos fundamentais, os quais, imprescindivelmente, merecem ser observados.

Contudo, não é o objetivo desse trabalho examinar todos esses limites, de modo que se pretende dar enfoque à questão da aplicação de multa cominatória em face do descumprimento de ordens judiciais ligadas a exibição de documentos por parte dos integrantes do polo passivo em demandas de ação popular e suas eventuais limitações.

Adentrando propriamente na temática que se pretende desenvolver neste momento, ressalta-se que a multa diária (astreintes), como exemplo de meio típico, já é utilizada plenamente nas obrigações de fazer e não fazer, e de entrega de coisa certa: é a multa cominada pelo juiz para assegurar o cumprimento da sua decisão, e tem por objetivo forçar o réu a adimplir. Possui, portanto, caráter coercitivo, devida independentemente de indenização e deve ser fixada com base em critérios que proporcionem a efetividade da tutela jurisdicional. Luiz Guilherme Marinoni observa ainda que para essa fixação deve ser considerada a capacidade econômica daquele a quem o mandamento judicial é dirigido. (MARINONI, 2003, p. 215-216).

Assim, é considerada um mecanismo eficaz para que o demandado cumpra com a obrigação: o indivíduo se vê diante de uma situação menos onerosa, que é tão somente o cumprimento da obrigação, e de uma situação mais onerosa, pois, além de continuar obrigado 
a prestar a tutela específica, ainda estará obrigado a cumprir com a multa diária. (BORGES, 2010, p. 121).

Não obstante tratar-se de mecanismo típico de efetivação dos provimentos jurisdicionais, cumpre destacar o posicionamento sumulado pelo Superior Tribunal de Justiça, cujo entendimento veda a aplicação de multa cominatória na ação de exibição de documentos $^{18}$, o que se apresenta, pois, como claro exemplo de limitação a aludida prerrogativa dos magistrados de tomar quaisquer decisões que objetivem satisfazer a tutela conferida.

Deste modo, insta salientar o que restou decidido pela Segunda Seção do STJ, em sede de recurso repetitivo, no REsp 1.333.988-SP, Rel. Min. Paulo de Tarso Sanseverino, julgado em 09/04/2014 e noticiado no Informativo ${ }^{\circ} 539$, ainda que se tratando de demanda cujo objeto consiste na discussão de relações entre particulares, atribui-se a seguinte interpretação à respectiva Súmula 372:

"Tratando-se de pedido deduzido contra a parte adversa, descabe multa cominatória na exibição, incidental ou autônoma, de documento relativo a direito disponível. No curso de uma ação que tenha objeto próprio, distinto da exibição de documentos, a consequência da recusa em exibi-los é a presunção de veracidade, por disposição expressa do art. 359 do CPC. Sendo assim, a orientação da jurisprudência do STJ é no sentido do descabimento de astreintes na exibição incidental de documentos. [...] No entanto, a presunção é relativa, podendo o juiz decidir de forma diversa da pretendida pelo interessado na exibição com base em outros elementos de prova constantes dos autos. Nesse caso, no exercício dos seus poderes instrutórios, pode o juiz até mesmo determinar a busca e apreensão do documento, se entender necessário para a formação do seu convencimento. [...] Quanto à ação de exibição de documentos, o STJ possui entendimento consolidado na Súmula 372: "Na ação de exibição de documentos, não cabe a aplicação de multa cominatória". Também não cabe a presunção de veracidade do art. 359 do CPC (REsp 1.094.846-MS, julgado sob o rito do art. 543- C do CPC, DJe 3/6/2009)." [grifou-se]

${ }^{18}$ Súmula 372/STJ: "Na ação de exibição de documentos, não cabe a aplicação de multa cominatória." (2009). Precedentes: AgRg no Ag 828.342-GO (3 $3^{\mathrm{a}} \mathrm{T}, 18.10 .2007$ - DJ 31.10.2007); REsp 204.807-SP ( $3^{\mathrm{a}} \mathrm{T}$, 06.06.2000 - DJ 28.08.2000); REsp 433.711-MS ( $3^{\mathrm{a}} \mathrm{T}$, 25.02.2003 - DJ 22.04.2003); REsp 633.056-MG ( $3^{\mathrm{a}}$ T, 12.04.2005 - DJ 02.05.2005); REsp 981.706-SP (4 ${ }^{\mathrm{a}} \mathrm{T}, 09.10 .2007-\mathrm{DJ}$ 12.11.2007). 
Portanto, conforme se constata no posicionamento retro explicitado, a consequência da recusa em apresentar a documentação fixada pelo mandamento judicial é a aplicação da presunção de veracidade do alegado pela parte que requereu a exibição dos documentos, não sendo possível a aplicação de multa cominatória como meio coercitivo ao cumprimento do mandamento judicial.

Resta evidente, portanto, que, segundo a sistemática adotada pelo Superior Tribunal de Justiça, a sanção em face do descumprimento da decisão que ordenou a exibição de documentos, é presunção de veracidade dos fatos narrados no que se refere a documentação objeto da exibição. Em outras palavras, a versão apontada pelo autor seria, presumidamente, tida por verdadeira independentemente de estar ou não de acordo com a realidade documental.

Com efeito, percebe-se pela natureza do direito ora discutido, que tal entendimento surgiu no âmbito do direito privado; sendo, portanto, indiscutível sua aplicação nesse contexto. O que se pretende suscitar, neste trabalho, é a utilização analógica de tal raciocínio ao direito público, notadamente em sede de processos de ação popular.

Ainda na esteira da lógica processual acima mencionada, no qual se encontra o gestor público obrigado a juntar aos autos determinados documentos de licitação que; por ser lesiva ao patrimônio público, objetiva-se anular; não foram disponibilizados voluntariamente ao postulante, em sede de ação popular, restaria inviabilizada a cominação de multa em face de descumprimento, em atenção ao enunciado da Súmula 372 do Superior Tribunal de Justiça?

Por outro lado, questiona-se, igualmente, se é digna de discussão a possibilidade de aplicação da aludida presunção de veracidade, a qual teria o condão, inclusive, de representar espécie de presunção de ato de improbidade contra o gestor ou contra a Fazenda Pública.

Sobre a ótica do processo que envolve interesses da administração, outro fato que merece destaque são as prerrogativas processuais da Fazenda Pública, sobretudo à luz do princípio da supremacia do interesse público, alicerce de todo o direito público. Sendo assim, há de se mencionar a indisponibilidade do interesse público, sob o fundamento de que, consoante os ensinamentos de Maria Sylvia Zanella di Pietro: “A Administração Pública não 
é titular do interesse público, mas apenas sua guardiã; ela tem que zelar pela sua proteção. Daí a indisponibilidade do interesse público”. (DI PIETRO, 1991, p. 163).

Seguindo essa linha, vale realizar uma digressão ao estudo do fenômeno da revelia, nota-se que, sendo ré a Fazenda Pública, não se verifica a produção de um de seus mais importantes efeitos, qual seja, a presunção de veracidade dos fatos alegados pelo autor, eis que o direito da entidade estatal é indisponível, ${ }^{19}$ devendo o magistrado, ainda que ocorra a revelia, determinar a instrução da lide, a fim de que a parte promovente possa cumprir seu ônus probandi. Isso porque a situação supramencionada consiste em hipótese de afastamento da incidência da regra contida no art. $344^{20}$ do NCPC, de acordo com o art. 345, II: “A revelia não produz o efeito mencionado no art. 344 se: [...] II - o litígio versar sobre direitos indisponíveis". Nesse sentido, é firme o entendimento no Superior Tribunal de Justiça, conforme se observa:

TRIBUTÁRIO, PROCESSUAL CIVIL E ADMINISTRATIVO. FAZENDA PÚBLICA. DIREITOS INDISPONÍVEIS. INAPLICABILIDADE DOS EFEITOS DA REVELIA. ART. 320, INCISO II, DO CPC. IPTU. LANÇAMENTO. ATO ADMINISTRATIVO. PRESUNÇÃO DE VERACIDADE. MODIFICAÇÃO POR LAUDO TÉCNICO UNILATERAL. IMPOSSIBILIDADE. PROVA INEQUÍVOCA.

1. Não se aplicam os efeitos da revelia contra a Fazenda Pública uma vez que indisponíveis os interesses em jogo.

2. O ato administrativo goza da presunção de legalidade que, para ser afastada, requer a produção de prova inequívoca cujo valor probatório não pode ter sido produzido unilateralmente pelo interessado.

3. Agravo regimental improvido. (AgRg no REsp 1137177/SP, Rel. Ministro HUMBERTO MARTINS, SEGUNDA TURMA, julgado em 18/02/2010, DJe 02/03/2010) [grifou- se]

\footnotetext{
${ }^{19}$ Leonardo Cunha, ao explorar o tema da revelia quando revel a Fazenda Pública, sustenta não haver a produção dos efeitos materiais da revelia, senão vejamos: "O que importa deixar assente é que, sendo ré a Fazenda Pública, não se opera, quanto aos fatos alegados pelo autor, a presunção de veracidade decorrente da revelia. Sabe-se que a presunção relativa não poderia ter o condão de afastar a presunção de legitimidade dos atos administrativos. Daí a necessidade de haver prova a ser produzida pelo autor, mesmo que a Fazenda Pública ostente a condição de revel". (CUNHA, 2012, p. 100).

${ }^{20}$ Tem-se como principal efeito material da revelia a presunção de veracidade dos fatos narrados pelo postulante na inicial (Art. 344. Se o réu não contestar a ação, será considerado revele presumir-se-ão verdadeiras as alegações de fato formuladas pelo autor).
} 
Destarte, considerando a indisponibilidade do interesse público, seria demasiado imprudente oportunizar o emprego da presunção de veracidade em processos de ação popular, conforme preconiza o Superior Tribunal de Justiça, nas quais figurem como demandados gestores públicos ou a própria Fazenda Pública, haja vista que os atos administrativos gozam de presunção de legitimidade.

Portanto, parece mais prudente sustentar que deve permanecer com o autor o ônus de comprovar as alegações contidas em sua petição inicial, sob pena de configurar a improcedência da lide. (CUNHA, 2012, p. 99).

Diante desse cenário, onde, segundo o Superior Tribunal de Justiça, não cabe a aplicação de multa cominatória no que se refere à exibição de documentos, bem como por decorrência lógica do princípio da indisponibilidade do interesse público, não seria cabível a presunção de veracidade dos fatos narrados, enquanto não forem exibidos os documentos relativos ao pleito autoral, restaria ao autor popular se conformar e ver sua demanda ser extinta por falta de provas?

Não parece esta ser a solução mais coerente, pois, nas ações populares, ao contrário do que se imagina em um primeiro momento, o interesse público não figura como argumento favorável aos demandados, ainda que fazendários, pois o autor está a exercer prerrogativa que lhe é assegurada constitucionalmente na defesa do patrimônio público. Logo, a narrativa que sustenta a impossibilidade de presunção de veracidade dos fatos alegados com base no “interesse público", mostra-se, na verdade, como uma tentativa retórica de induzir a erro sobre o que seria o real interesse público desenvolvido no processo de ação popular, ou seja, distorcendo o papel do autor popular como se este buscasse provimento contrário ao interesse público, quando, na realidade, busca o cumprimento dos corolários administrativos com o instrumento que lhe foi conferido.

Ademais, urge enaltecer ainda que tanto o princípio da publicidade insculpido no artigo 37 da Constituição Federal, quanto a Lei de Acesso a Informação (Lei $\mathrm{n}^{\circ} 12.527$ de 2011), a Lei de Licitações (Lei $n^{\circ}$ 8.666, de 1993) e a Lei do Processo Administrativo Federal (Lei $n^{\circ}$ 9.784, de 1999) trazem a obrigatoriedade de que os entes e gestores públicos possibilitem o acesso a todas as informações públicas, salvo nas expressas e específicas situações legais. Deste modo, quando no curso do processo de ação popular há a negativa ou a 
omissão no que se refere à exibição de documentos, além de desobedecer claro provimento jurisdicional, se está afrontando a legislação e a Constituição, de forma direta.

Isto posto, o que se pretende demonstrar, por meio de colocações tais como o exemplo acima disposto, é que, apesar de alguns, equivocadamente, sustentarem a impossibilidade de presunção de veracidade dos fatos narrados pelo autor popular, tal argumento não deve prevalecer pois mostra nítida inversão de valores, que acabaria por transportar o mecanismo da ação popular para a já tão assoberbada vala da crise de satisfação que assola a realidade processual brasileira.

\section{CONSIDERAÇÕES FINAIS}

A crise da execução, ou mesmo a crise do processo, é fenômeno recorrente não apenas no direito brasileiro. Numa tentativa de mudar esse panorama, foram realizadas várias reformas nas leis processuais, mas o problema persiste, razão pela qual se percebe que as causas não estão apenas na legislação.

Especificamente em relação à satisfação da tutela, há meios disponíveis para que o magistrado consiga assegurar a prestação jurisdicional, tanto coercitivos quanto subrogatórios. Entretanto, nem sempre as medidas executivas previstas na lei são aptas a produzir um resultado eficaz e efetivo na entrega da prestação.

O dogma da tipicidade dos meios executivos foi quebrado pela redação dada ao $\S 5^{\circ}$ do art. 461 do antigo Código de Processo Civil, repetida no art. 536 do novo Código de Processo Civil. Permite-se assim ao juiz liberdade de escolha dos meios mais eficazes para o cumprimento das suas decisões.

Paralelamente, constata-se que a ação popular, mecanismo previsto constitucionalmente para viabilizar o exercício da democracia direta, mostra-se como uma das formas mais específicas e diretas de obtenção de uma proteção satisfatória dos bens jurídicos de titulares indeterminados. Ocorre que, no entanto, a dificuldade em fazer cumprir as decisões judiciais proferidas nesse contexto apresenta-se como um dos maiores entraves ao sucesso do instituto. 
Na verdade, a crise da execução, ou melhor: a "problemática da efetividade" é motivo recorrente de preocupação no direito brasileiro. Numa tentativa de mudar esse panorama, foram realizadas várias reformas nas leis processuais, o que acabou por intensificar, consideravelmente, os poderes conferidos aos magistrados para garantir a eficácia dos provimentos judiciais.

No que se refere ao estudo de eventuais limitações impostas a tal prerrogativa dos magistrados, não se deve entender, tão somente em virtude da redação dada ao aludido artigo, pela inexistência de balizas à atuação do judiciário no intuito de obter o êxito das decisões. Desse modo, como principal óbice, destacam-se os direitos e as garantias fundamentais introduzidos no ordenamento jurídico.

Com o fito de demonstrar a presença de limitações trazidas pela própria legislação e pela jurisprudência assente no país, apresenta-se como exemplo a análise da possibilidade de aplicação de multa cominatória em face do descumprimento de ordens judiciais por parte dos demandados em processos de ação popular.

Sendo assim, ressaltando-se, como obstáculo desse cenário, o enunciado da Súmula 372 do Superior Tribunal de Justiça, que veda a incidência de multa cominatória em se tratando de ação de exibição de documentos, bem como o Informativo $n^{\circ} 539$ do STJ, que trata das consequências da recusa em exibir os documentos requeridos, sobretudo a presunção de veracidade, por previsão expressa no atual diploma processual.

Dessa feita, questiona-se acerca da possibilidade de aplicar, como sanção à inércia diante do mandamento judicial, a presunção de veracidade no âmbito do direito público, utilizando-se do mesmo raciocínio adotado quando da relação entre particulares. Alguns negam tal possibilidade com base no suposto fato de que não se pode olvidar as prerrogativas da Fazenda Pública, notadamente o princípio da indisponibilidade do interesse público, que se apresentaria, como entrave à discussão supramencionada.

Desse modo, ante todas essas colocações, que não tiveram o condão de exaurir o tema, conclui-se apontando que no processo de ação popular, a argumentação do interesse público é prerrogativa do autor, que está a tentar anular o ato da administração pública, exatamente por este ser incompatível com o panorama publicista. Assim, por consequência, possível se mostra a presunção de veracidade dos fatos narrados na inicial, no que se refere à 
documentação, quando, intimado para apresenta-la em juízo, o polo passivo não o faz, tudo isso no intuito de proporcionar ao cidadão e à sociedade a completa satisfação de seus direitos.

\section{REFERÊNCIAS}

ALVARO DE OLIVEIRA, Carlos Alberto. Direitos fundamentais à efetividade e à segurança em perspectiva dinâmica, Revista de Processo, n. 155. São Paulo: Revista dos Tribunais, 2008.

BORGES, Rodrigo Lanzi de Moraes. Os meios expropriatórios após a nova sistemática da execução civil por quantia certa contra solvente e a possibilidade de aplicação da multa diária (astreintes). Revista Dialética de Direito Processual. São Paulo: Dialética, 08/2010. p. 114135.

BRASIL. Constituição Federal, de 5 de outubro de 1988.

Lei $\mathbf{n}^{\mathbf{0}}$ 4.717, de 29 de junho de 1965.

Lei no 5.869, de 11 de janeiro de 1973.

Lei $\mathbf{n}^{\mathbf{0}} \mathbf{8 . 6 6 6}$, de 21 de junho de 1993.

Lei n⿳ 9.784, de 29 de janeiro de 1999.

Lei $\mathbf{n}^{\mathbf{0}} \mathbf{1 2 . 5 2 7}$, de 18 de novembro de 2011 .

Lei $\mathbf{n}^{\mathbf{0}} \mathbf{1 3 . 1 0 5}$, de 16 de março de 2015 .

. Superior Tribunal de Justiça. 1.333.988 - SP (20120144161-8). Relator: Ministro

Paulo De Tarso Sanseverino, Data de Julgamento: 09/02/2010, QUARTA TURMA, Data de

Publicação: $\quad$ 09/04/2014. Disponível em:

<http://stj.jusbrasil.com.br/jurisprudencia/25043003/recurso-especial-resp-1333988-sp-2012-

0144161-8-stj/inteiro-teor-25043004>. Acessado em: 17/03/2016. 
Superior Tribunal de Justiça. Informativo no 539. Data de Publicação: 2014.

Disponível em: <https://ww2.stj.jus.br/jurisprudenciaexterno/informativo>. Acessado em: $17 / 03 / 2016$.

- Superior Tribunal de Justiça. AGRAVO REGIMENTAL NO RECURSO ESPECIAL: AgRg no REsp 1137177 SP 2009/0079627-9. Relator: Ministro Humberto Martins, Data de Julgamento: 18/02/2010, SEGUNDA TURMA, Data de Publicação: 02/03/2010). Disponível em: <http://stj.jusbrasil.com.br/jurisprudencia/19164394/agravoregimental-no-recurso- especial-agrg-no-resp-1137177-sp-2009-0079627-9>. Acessado em: 17/03/2016.

BUENO, Cássio Scarpinella. Ensaio sobre o cumprimento das sentenças condenatórias. Revista de processo, v. 113, p. 22-76, 2004.

Curso sistematizado de direito processual civil: tutela jurisdicional executiva. vol. 3. 7. ed. São Paulo, 2013.

CABRRAL, Trícia Navarro Xavier. Poderes do juiz no novo CPC. Revista de Processo. vol. 208. São Paulo, 2012.

CUNHA, Leonardo Carneiro. A fazenda pública em juízo. 10. ed. São Paulo: Dialética, 2012.

DI PIETRO, Maria Sylvia Zanella. Discricionariedade Administrativa na Constituição de 1988. São Paulo: Atlas, 1991.

DINAMARCO, Cândido Rangel. A nova era do processo civil. 2. ed. São Paulo: Malheiros, 2007.

A instrumentalidade do Processo. 14 ed. São Paulo: Malheiros, 2009.

GUERRA, Marcelo Lima. Direitos Fundamentais e a proteção do credor na execução civil. São Paulo: RT, 2003.

MARINONI, Luiz Guilherme. As novas sentenças e os novos poderes do juiz para a prestação da tutela jurisdicional efetiva. Genesis Revista de Direito Processual Civil. n. 29, jul./set. 2003. 
Tutela inibitória: individual e coletiva. 3. ed. São Paulo: RT, 2003.

A legitimidade da atuação do juiz a partir do direito fundamental à tutela jurisdicional efetiva. Revista da Escola Nacional da Magistratura, ano I. 2005.

MELlO, Celso Antônio Bandeira de Mello. Curso de Direito Administrativo. 26. ed. São Paulo: Malheiros, 2008.

REIS, Ulisses Levy Silvério dos. Ação popular constitucional. Revista Jus Navigandi. n. 3969. Teresina, mai. 2014.

VIANA, Juvêncio Vasconcelos. Nova execução civil. Fortaleza: Pouchain Ramos, 2007.

WAMBIER, Teresa Arruda Alvim et all. Breves Comentários ao Código de Processo Civil. São Paulo: Revista dos Tribunais, 2015.

ZAVASCKI, Teori Albino. Título executivo e liquidação. 2. ed. São Paulo: RT, 2001. 